\title{
CHEMICAL PROFILES AND ANTIBACTERIAL, ANTIOXIDANT, CYTOTOXIC ACTIVITIES OF ACETONE EXTRACT FROM LEAVES OF HELICTERES HIRSUTA LOUR.
}

\author{
NHAT TAM LE ${ }^{1}$, HONG THIEN VAN ${ }^{1}$, NGOC TRUC PHUONG NGUYEN ${ }^{1}$, VAN SON LE ${ }^{2}$, VAN \\ HAI CHU ${ }^{3}$, HUYNH ANH VU TRUONG ${ }^{3}$, QUOC HUNG NGUYEN ${ }^{3}$, HOANG DUNG NGUYEN $^{4}$, \\ NGOC NAM TRINH ${ }^{5}$, TAN VIET PHAM ${ }^{1}$ \\ ${ }^{I}$ Institute of Biotechnology and Food technology, Industrial University of Ho Chi Minh City \\ ${ }^{2}$ Binh Chau-Phuoc Buu Nature Reserve, Bung Rieng Ward, Xuyen Moc District, Ba Ria-Vung Tau \\ Province \\ ${ }^{3}$ Center of Analytical Services and Experimentation HCMC \\ ${ }^{4}$ Institute of Tropical Biology, Vietnam Academy of Science and Technology \\ ${ }^{5}$ Office of Science Management and International Affairs, Industrial University of Ho Chi Minh City \\ phamtanviet@iuh.edu.vn
}

\begin{abstract}
The present study, twenty-five chemical compounds of acetone extract from the Helicteres hirsuta leaves have been investigated for the first time using GC-MS, in which neophytadiene, palmitic acid methyl ester, palmitic acid, phytol, linolenic acid and octadecanoic acid were identified as the major constituents. By using disk-diffusion assay, the results showed that the extract was resistant against 6 studied bacterial strains, including Escherichia coli, Pseudomonas aeruginosa, Salmonella enteritidis, Salmonella typhimurium, Bacillus cereus and Staphylococcus aureus. Furthermore, the DPPH and MTT methods were used to identify the antioxidant and cytotoxic activities of the studied extract. As a result, the cytotoxicity of the extract against the Hepatoma (Hep-G2) cell line was indicated with the $\mathrm{IC}_{50}$ of 381.8 $\mathrm{ppm}$ whereas this value was $1.223 \mathrm{mg} / \mathrm{mL}$ in DPPH inhibition.
\end{abstract}

Keywords: Helicteres hirsuta; GC/MS; antibacterial, antioxidant, cytotoxic activities; acetone extract.

\section{INTRODUCTION}

Helicteres L., the large genus belonging to Malvaceae family, includes approximately 60 species distributed in tropical regions of Asia and America [1,2] Nine species are known from Vietnam, including $H$. angustifolia, H. daknongensis, H. elongate, H. lannata, H. isora, H. lanceolate, H. poilanei, H. viscida and $H$. hirsute [3]. Many species of the Helicteres genus are remedies used in Vietnam and other countries traditional medicine as anti-inflammatory agents, vermifuges and tonic agents. [3]

Helicteres hirsuta is a small shrub growing mostly in Australia and Southest Asia [4]. This species was recorded in some regions of Southern Vietnam, including Binh Phuoc, Kien Giang, Khanh Hoa and Ba RiaVung Tau Province [3, 4]. The chemical compounds and bioactivities of various extracts which were isolated from the different solvents of this species have been reported by previous studies [3, 5-8]. To date, the chemical profiles and biological activities of acetone extract of $H$. hirsuta leaves are limited, however. In this study, the chemical constituents, antibacterial, antioxidant and cytotoxic activities of the acetone extract of $H$. hirsuta leaves were investigated for the first time.

\section{METHODS AND MATERIALS}

\subsection{Plant}

Specimens of Helicteres hirsuta were collected from Binh Chau-Phuoc Buu Nature Reserve, Bung Rieng ward, Xuyen Moc District, Ba Ria-Vung Tau Province, Vietnam (10³1'32.2"N 107²8'46.1"E, July 2, 2020) (Figure 1). The voucher specimen (VS Le 512) was deposited at the herbarium of Binh Chau-Phuoc Buu Nature Reserve. 

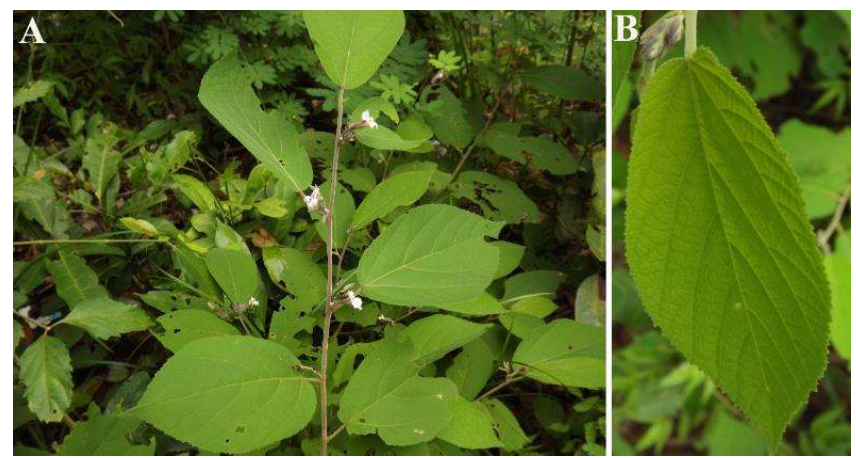

Figure 1. Helicteres hirsuta. A. The species in habitat, B. Leaf

\subsection{Bacterial strains}

Six bacterial strains were used to investigate the antibacterial activity of the acetone extract from the leaves of H. hirsuta, including Escherichia coli (ATCC 25922), Pseudomonas aeruginosa (ATCC 27853), Salmonella enteritidis (ATCC 13976), Salmonella typhimurium (ATCC 13311), Bacillus cereus (ATCC 11774) and Staphylococcus aureus (ATCC 25923). These strains were preserved in $20 \%$ glycerol solution at $20^{\circ} \mathrm{C}$ and cultivated in Luria-Bertani broth at $37^{\circ} \mathrm{C}$ for $24 \mathrm{~h}$ to activate prior to antibacterial activity assay.

\subsection{Extraction procedures}

The fresh $H$. hirsuta leaves were sliced into small pieces and modestly dried at $50^{\circ} \mathrm{C}$ until constant weight. The specimens were pulverized into powder. $100 \mathrm{~g}$ of the dried powders were subsequently macerated in $250 \mathrm{~mL}$ of acetone $99 \%$ solution at room temperature for 72 hours. The Whatman paper was used to filter the extract. The extraction from the dried powders was repeated twice to collect the filtrate. The filtrate was condensed under vacuum pressure at $60^{\circ} \mathrm{C}$ to obtain the brown extract. The brown extract was in a syrup form and it was used for further experiments [9].

\subsection{Gas chromatography/mass spectrometry (GC/MS) analysis}

The GS/MS assay was conducted on the TRACE 1310 Gas Chromatograph (Thermo Fisher Scientific Inc., Waltham, MA, USA) combined with ISQ 7000 single quadrupole mass spectrometer. This process used the DB-5MS 30m, $0.25 \mathrm{~mm}, 0.25 \mu \mathrm{m}$ column and the carrier gas was helium with the column flow rate of $1.2 \mathrm{~mL} / \mathrm{min}$. Sample was injected into the system with the inlet temperature of $250^{\circ} \mathrm{C}$, the split ratio of $30: 1$, the splitless mode of $1 \mathrm{~min}$ and the split flow of $36 \mathrm{~mL} / \mathrm{min}$. The oven temperature was initially set at $80^{\circ} \mathrm{C}$ and hold for $5 \mathrm{~min}$. The temperature was then programmed to increase up to $280^{\circ} \mathrm{C}$ at the rate $20 \mathrm{C} / \mathrm{min}$ and hold for $10 \mathrm{~min}$. The electron ionization mode and the ion source temperature used were $70 \mathrm{eV}$ and $250^{\circ} \mathrm{C}$, respectively. The mass scan range was of $29-650 \mathrm{~m} / \mathrm{z}$. To identify the chemical constituents of the studied samples, the internal library, including NIST 2017 library and the Wiley $8^{\text {th }}$ edition libraries were used.

\subsection{Antibacterial activity asay}

The antibacterial activity assay was conducted by disc diffusion method following the CLSI guideline [10]. Mueller Hinton Broth was used to culture the six bacterial strains until the turbidity of the cultures reached $0.5 \mathrm{Mc}$ Farland Standard. Mueller Hinton agar plate was inoculated by spreading with $0.1 \mathrm{~mL}$ of the bacterial culture. The paper discs were impregnated with $10 \mu \mathrm{L}$ of acetone extracts. The Gentamycin containing discs (Nam Khoa BioTek Company, Vietnam) $(10 \mu \mathrm{g} / \mathrm{mL})$ were used as positive controls whereas the DMSO solution was used as the negative controls. Then the plates were incubated at $37^{\circ} \mathrm{C}$ for 24 hours, and the diameters of the inhibition zones of extract against tested bacteria were recorded.

Three biological replicates were used for the experiment and the results were expressed as as mean \pm standard deviation (SD). The differences between means groups were calculated by Fisher's least significant difference (LSD) procedure using Statgraphics Centurion XV software (Statpoint Technologies Inc, Virginia, USA) with $p<0.05$.

\subsection{Determination of antioxidant activity of extract}

The method described by Thaipong et al. was used to identify the DPPH (2,2-diphenyl-1-picrylhydrazyl) radical scavenging activity of the extract. The $100 \mu \mathrm{L}$ of the studied extract was added to $100 \mu \mathrm{L}$ of DPPH solution $(300 \mu \mathrm{M})$. The mixture was then slightly shaken and placed in dark $30 \mathrm{~min}$ at $37^{\circ} \mathrm{C}$. The absorbance of the solution was later recorded at $517 \mathrm{~nm}$ and the DPPH radical scavenging activity (DPPH $\mathrm{RSA}$ ) of the extract was calculated according to the following formula: 
$\mathrm{DPPH}_{\mathrm{RSA}}(\%)=\left(\mathrm{Abs}_{\text {control }}-\mathrm{Abs}_{\text {sample }}\right) / \mathrm{Abs}_{\text {control }} \times 100 \%$

where $\mathrm{Abs}_{\text {control }}$ is the absorbance of the DPPH radical in methanol and $\mathrm{Abs}_{\text {sample }}$ is the absorbance of the DPPH radical solution mixed with the sample extract [11].

\subsection{Cytotoxicity assay}

Hep-G2 cell line (ATCC HB-8065), USA) was used to investigate the cytotoxicity of the acetone extract from the leaves of $H$. hirsuta following MTT method [12]. The assay was conducted in 96 well - plate format, in which Hep-G2 cell line $\left(10^{4}\right.$ cells/well) was grown in RPMI 1640 medium (Gibco Invitrogen, USA) containing 10\% heat-inactivated fetal bovine serum (Sigma Aldrich, USA), $100 \mathrm{U} / \mathrm{mL}$ penicillin (Sigma Aldrich, USA) and $100 \mu \mathrm{g} / \mathrm{mL}$ streptomycin (Sigma Aldrich, USA) at $37^{\circ} \mathrm{C}$ and $5 \% \mathrm{CO}_{2}$. DMSO was the solvent of tested compounds. The compounds were stepwise diluted to the final concentration of $0-200 \mathrm{lg} / \mathrm{mL}$ after $24 \mathrm{~h}$ of incubation. Cisplatin was used as a positive control. Three biological replicates were used for the experiment. $\mathrm{IC}_{50}$ values (concentration of the compound which have $50 \%$ inhibition on the cell growth) was recorded.

\section{RESULTS AND DISCUSSION}

\subsection{Chemical composition}

The chemical constituents of acetone extract from $H$. hirsuta leaves were presented in Table 1 , in which a total of 25 compounds have been identified. According to gas chromatogram (Figure 2), six compounds, including neophytadiene, palmitic acid methyl ester, palmitic acid, phytol, linolenic acid and octadecanoic acid which stated in retention time values $12.69,13.14,13.33,14.08,14.20$ and 14.30 , respectively are the major constituents.

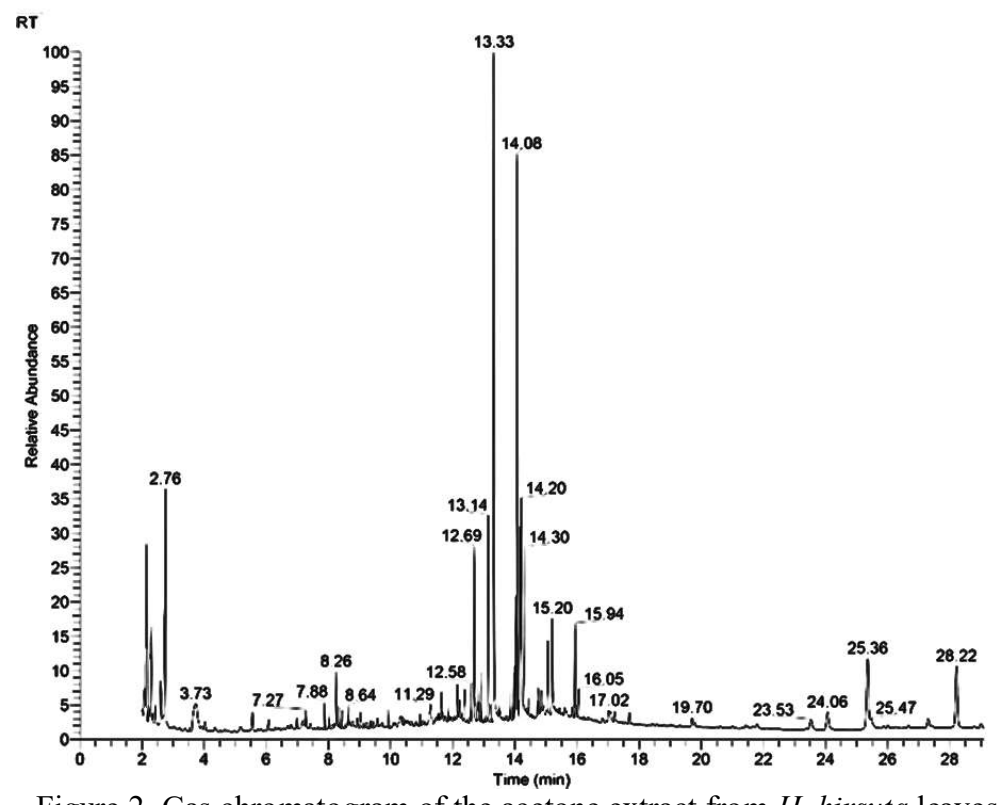

Figure 2. Gas chromatogram of the acetone extract from $H$. hirsuta leaves

The biological activities of six main constituents presented in the acetone extract of H. hirsuta leaves in present study have been documented in previous studies. For instance, neophytadiene was known to have antimicrobial and anti-inflammatory agent as well as a plant metabolite and an algal metabolite [13-15]. Palmitic acid methyl ester is a compound which has the ability to inhibit Kupffer cells, the resident macrophages in the liver regulating inflammatory processes by secretion of TNFalpha and NO [16]. Furthermore, this constituent also exhibits anti-fibrotic effects [17] as well as acts as potent vasodilator released in retina and myometrium [18-20]. Agoramoorthy et al. (2007) showed that palmitic acid, a major compound which isolated from leaves of Excoecaria agallocha has a role as antibacterial and antifungal agent [21]. Phytol, an abundant compound in nature, is known to have the antinociceptive, antibacterial, antioxidant, cytotoxic activities as well as the anxiolytic and anticonvulsant effect [22]. Linolenic acid, a 
fatty acid found mostly in plant, has a role as anti-inflammatory agent [23]. Furthermore, Jerah et al. demonstrated that octadecanoic acid isolated from Cymbopogon nardus could inhibit against measles virus and Vero cell line [24].

Table 1. Chemical constituents of acetone extract from the leaves of H. hirsuta

\begin{tabular}{|c|c|c|c|}
\hline No. & $\begin{array}{c}\text { Retention } \\
\text { Time }\end{array}$ & Compounds & $\begin{array}{c}\text { Molecular } \\
\text { Formula }\end{array}$ \\
\hline 1 & 2.15 & 2-Pentanone, 4-hydroxy-4-methyl- & $\mathrm{C}_{6} \mathrm{H}_{12} \mathrm{O}_{2}$ \\
\hline 2 & 2.30 & 1-Methoxy-2-propyl acetate & $\mathrm{C}_{6} \mathrm{H}_{12} \mathrm{O}_{3}$ \\
\hline 3 & 2.76 & Ethanol, 2-butoxy- & $\mathrm{C}_{6} \mathrm{H}_{14} \mathrm{O}_{2}$ \\
\hline 4 & 3.73 & Glycerin & $\mathrm{C}_{3} \mathrm{H}_{8} \mathrm{O}_{3}$ \\
\hline 5 & 6.07 & Maltol & $\mathrm{C}_{6} \mathrm{H}_{6} \mathrm{O}_{3}$ \\
\hline 6 & 6.99 & Isophorone & $\mathrm{C}_{9} \mathrm{H}_{14} \mathrm{O}$ \\
\hline 7 & 7.27 & 4H-Pyran-4-one, 2,3-dihydro-3,5-dihydroxy-6-methyl- & $\mathrm{C}_{6} \mathrm{H}_{8} \mathrm{O}_{4}$ \\
\hline 8 & 8.02 & 12-Heptadecyn-1-ol & $\mathrm{C}_{17} \mathrm{H}_{32} \mathrm{O}$ \\
\hline 9 & 8.24 & 5-Hydroxymethylfurfural & $\mathrm{C}_{6} \mathrm{H}_{6} \mathrm{O}_{3}$ \\
\hline 10 & 8.36 & 1H-Pyrrole-2,5-dione, 3-ethyl-4-methyl- & $\mathrm{C}_{7} \mathrm{H}_{9} \mathrm{NO}_{2}$ \\
\hline 11 & 8.44 & 1,2,3-Propanetriol, 1 -acetate & $\mathrm{C}_{5} \mathrm{H}_{10} \mathrm{O}_{4}$ \\
\hline 12 & 8.64 & 1H-Pyrrole-2,5-dione, 3-ethenyl-4-methyl- & $\mathrm{C}_{7} \mathrm{H}_{7} \mathrm{NO}_{2}$ \\
\hline 13 & 11.64 & 9,12,15-Octadecatrienoic acid, 2,3-dihydroxypropyl ester, (Z,Z,Z)- & $\mathrm{C}_{21} \mathrm{H}_{36} \mathrm{O}_{4}$ \\
\hline 14 & 12.15 & 4-((1E)-3-Hydroxy-1-propenyl)-2-methoxyphenol & $\mathrm{C}_{10} \mathrm{H}_{12} \mathrm{O}_{3}$ \\
\hline 15 & 12.38 & 6-Hydroxy-4,4,7a-trimethyl-5,6,7,7a-tetrahydrobenzofuran-2(4H)-one & $\mathrm{C}_{11} \mathrm{H}_{16} \mathrm{O}_{3}$ \\
\hline 16 & 12.69 & Neophytadiene & $\mathrm{C}_{20} \mathrm{H}_{38}$ \\
\hline 17 & 12.92 & 3,7,11,15-Tetramethyl-2-hexadecen-1-ol & $\mathrm{C}_{20} \mathrm{H}_{40} \mathrm{O}$ \\
\hline 18 & 13.14 & Palmitic acid methyl ester & $\mathrm{C}_{17} \mathrm{H}_{34} \mathrm{O}_{2}$ \\
\hline 19 & 13.33 & Palmitic acid & $\mathrm{C}_{16} \mathrm{H}_{32} \mathrm{O}_{2}$ \\
\hline 20 & 14.08 & Phytol & $\mathrm{C}_{20} \mathrm{H}_{40} \mathrm{O}$ \\
\hline 21 & 14.17 & 9(E), 11(E)-Conjugated linoleic acid & $\mathrm{C}_{18} \mathrm{H}_{32} \mathrm{O}_{2}$ \\
\hline 22 & 14.20 & Linolenic acid & $\mathrm{C}_{18} \mathrm{H}_{30} \mathrm{O}_{2}$ \\
\hline 23 & 14.30 & Octadecanoic acid & $\mathrm{C}_{18} \mathrm{H}_{36} \mathrm{O}_{2}$ \\
\hline 24 & 15.94 & Hexadecanoic acid, 2-hydroxy-1-(hydroxymethyl)ethyl ester & $\mathrm{C}_{19} \mathrm{H}_{38} \mathrm{O}_{4}$ \\
\hline 25 & 28.22 & Glutinol & $\mathrm{C}_{30} \mathrm{H}_{50} \mathrm{O}$ \\
\hline
\end{tabular}

\subsection{Antibacterial activity of extract}

The present study showed that the acetone extract from the leaves of H. hirsuta could inhibit against 6 bacterial strains (Table 2). Among them, the extract exhibited the strongest antibacterial activity against $S$. aureus with the diameter of inhibition zone about $14.2 \pm 0.8 \mathrm{~mm}$, followed by $S$. typhimurium $(13.7 \pm 0.8 \mathrm{~mm})$, $P$. aeruginosa $(13.5 \pm 1.3 \mathrm{~mm}), S$. enteritidis $(12.1 \pm 1.3 \mathrm{~mm}), E$. coli $(11.3 \pm 1.0 \mathrm{~mm})$ and $B$. cereus $(91.3 \pm 0.3 \mathrm{~mm})$. According to the results which were presented in Table 2, the inhibition zones of the extract against 3 studied bacteria, including $P$. aeruginosa, S. enteritidis and S. aureus were larger than those of positive control. The findings, therefore, suggest the potential application of acetone extract of leaves as the antimicrobial agent.

Table 2. Inhibition zone of acetone extract isolated from $H$. hirsuta leaves against six bacterial strains

\begin{tabular}{lcc}
\hline \multicolumn{1}{c}{ Tested bacteria } & \multicolumn{1}{c}{ Growth inhibition zone (mm) } \\
\cline { 2 - 3 } & Studied sample & Positive control \\
\hline Bacillus cereus & $9.3 \pm 0.3^{\mathrm{a}}$ & $18.3 \pm 0.6^{\mathrm{b}}$ \\
\hline Escherichia coli & $11.3 \pm 1.0^{\mathrm{a}}$ & $13.5 \pm 0.5^{\mathrm{b}}$ \\
\hline Pseudomonas aeruginosa & $13.5 \pm 1.3^{\mathrm{b}}$ & $10.0 \pm 1.0^{\mathrm{a}}$ \\
\hline Salmonela enteritidis & $12.1 \pm 1.3^{\mathrm{b}}$ & $9.2 \pm 0.3^{\mathrm{a}}$ \\
\hline Salmonella typhimurium & $13.7 \pm 0.8^{\mathrm{a}}$ & $13.5 \pm 0.9^{\mathrm{a}}$ \\
\hline Staphylococcus aureus & $14.2 \pm 0.8^{\mathrm{b}}$ & $10.7 \pm 0.8^{\mathrm{b}}$ \\
\hline \multicolumn{2}{c}{${ }^{\mathrm{a}, \mathrm{b}}$ superscript letters indicate statistically different values, $\left.\mathrm{P}<0.05\right)$}
\end{tabular}


The previous study showed that the extracts isolated from the various fractions of $H$. hirsuta roots, including chloroform, ethyl acetate could inhibit the growth of $S$. aureus, whereas n-hexan, butanol fractions could inhibit the growth of Lactobacillus fermentum and no inhibitory was observed with E. coli, P. aeruginosa, $S$. enteritica [8]. In another study, Tran and Vo demonstrated that the methanolic extract of $H$. hirsuta aerial parts as well as its fractions exhibited the inhibition of the growth against 4 pathogenic bacteria such as E. coli, S. typhimurium, S. aureus and Streptococcus faecalis [25]. The study results showed that there were differences in the antibacterial activity of each $H$. hirsuta parts as well as the solvent used to extract compounds present in $H$. hirsuta. In addition, the inhibition of all 6 tested bacterial strains by acetone extract in this study showed the the effective extraction of antibacterial compounds from $\mathrm{H}$. hirsuta.

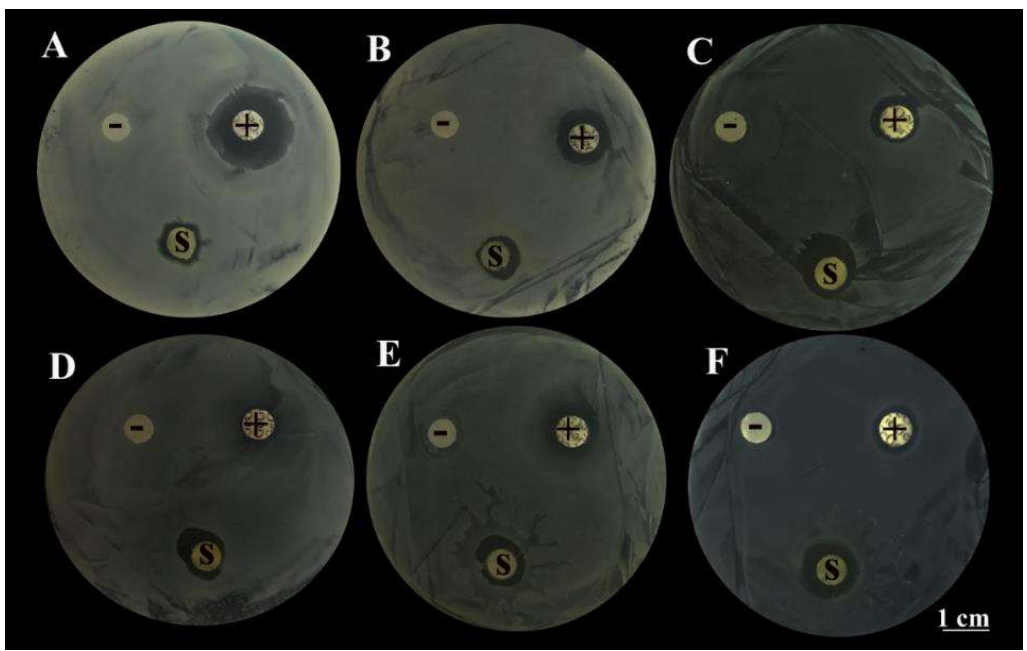

Figure 3. Antibacterial activity of acetone extract from $H$. hirsuta leaves against 6 bacterial strains. A. B. cereus, B.

E. coli, C. P. aeruginosa, D. S. enteritidis, E. S. typhimurium, F. S. aureus. (-) Negative control with sterilized distilled water, $(+)$ Positive control with discs containing gentamicin.

\subsection{Antioxidant and cytotoxic activity of extract}

The antioxidant activity of the acetone extract depended on the extract concentrations. An increase in $\mathrm{DPPH}_{\mathrm{RSA}}$ could be controlled by the increase in extract concentrations. The DPPH radical inhibition achieved over $72 \%$ at the maximum concentration of extract $(2.5 \mathrm{mg} / \mathrm{mL})$. The $\mathrm{IC}_{50}$ value of the extract was approximately $1.223 \mathrm{mg} / \mathrm{mL}$. The antioxidant activity of the various fractions isolated from $H$. hirsuta root has been identified by one previous study. Accordingly, five fractions, including n-hexan, chloroform, ethyl acetate, butanol and water showed the antioxidant activity through DPPH scavenging capacity which the $\mathrm{IC}_{50}$ values were $>1.6 \mathrm{mg} / \mathrm{mL}, 0.415 \mathrm{mg} / \mathrm{mL}, 0.117 \mathrm{mg} / \mathrm{mL}, 0.252 \mathrm{mg} / \mathrm{mL}, 0.951 \mathrm{mg} / \mathrm{mL}$, respectively [8]. Pham et al. demonstrated that the antioxidant capacity of methanol and water extracts of dried $H$. hirsuta leaves depened on the different drying conditions. The results showed that the $\mathrm{IC}_{50}$ values of hot-air drying, low-temperature-air drying, Infrared drying and vacuum drying methods of methanol extracts were 3.28 $\mathrm{mg} / \mathrm{g}, 3.35 \mathrm{mg} / \mathrm{g}, 3.01 \mathrm{~g} / \mathrm{mg}$ and $4.73 \mathrm{mg} / \mathrm{g}$, respectively whereas these values of water extract were 9.33 $\mathrm{mg} / \mathrm{g}, 5.09 \mathrm{mg} / \mathrm{g}, 2.46 \mathrm{mg} / \mathrm{g}, 13.45 \mathrm{mg} / \mathrm{g}$, respectively [26].

One human tumour cell line, hepatoma (Hep-G2), was inhibited by the acetone extract of $H$. hirsuta leaves. The results showed the $\mathrm{IC}_{50}$ value of the studied extract was $381.8 \mathrm{ppm}$, which causes $50 \%$ cell death. As mentioned above, the cytotoxic activity of the acetone extract isolated from the $\mathrm{H}$. hirsuta leaves have not been elucidated yet. Some previous studies, however, showed the various solvents as well as fractions. For instance, Diem et al. showed the cytotoxicity of $H$. hirsute root fractions on KB cell line. Accordingly, three fractions, including $\mathrm{n}$-hexan, ethyl acetate, butanol had cytotoxic effect on KB human cancer line which IC $_{50}$ values were $23.08 \mu \mathrm{g} / \mathrm{ml}, 3.23 \mu \mathrm{g} / \mathrm{ml}$ and $64.98 \mu \mathrm{g} / \mathrm{mL}$, respectively [8]. In another study, Nguyen and Le demonstrated that petroleum ether, dichloromethane extracts isolated from $H$. hirsuta root were able to inhibit HepG2 cell line which $\mathrm{IC}_{50}$ values were $28.29 \mu \mathrm{g} / \mathrm{mL}$ and $30.3 \mu \mathrm{g} / \mathrm{mL}$, respectively [5]. Quang et al. proved the cytotoxic activity of the chemical constituents isolated from methanol extracts of leaves, stems and roots of $H$. hirsute. The results showed that five cencer lines, including SK-LU-1, HepG2, Hela, 
SK-Mel-2 and AGS were killed by five compounds such as 3-O-trans caffeoylbetulinic acid, betulinic acid methyl ester, betulinic acid, lupeol and 5,8-dihydroxy-7,4-O-dimethoxyflavone [6]. Similarly, Nguyen et

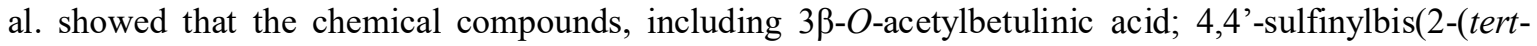
butyl)-5-methylphenol); 7-O-methylisoscutellarein; 7,4'-di- $O$-methylisoscutellarein, stigmasterol and $\beta$ sitosterol isolated from n-hexan, methylene chloride, ethyl acetate and methanol of $H$. hirsute aerial parts could inhibit four human cancer cell lines such as leukemia (CCRF-CEM), breast (MDA-MB-231), colon (HCT116) and glioblastoma (U251) [7].
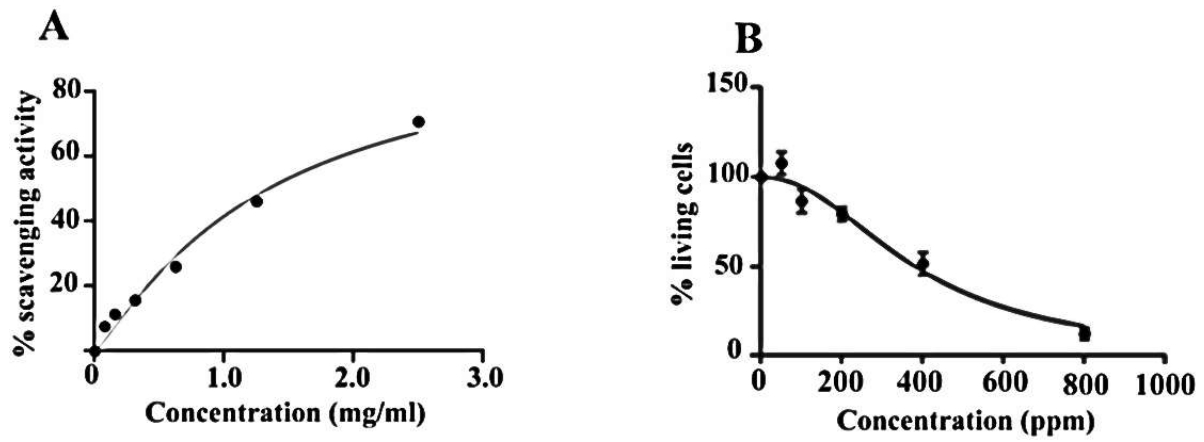

Figure 4. Radical scavenging activity (A) and cytotoxic activity (B) of the acetone extract from H. hirsuta leaves Previous research has shown that extracting the plant in various solvents such as acetone, ethanol, and ethylacetate has biological activity. Former researchers utilized hazardous solvents, such as chloroform and methanol, to get the bioactive fraction in their pharmacological investigations, thus these solvents should be suggested. Plant extracts with a limited level of solvents are not acceptable materials to employ in the formulation of goods, particularly those for human consumption. As a result, customers choose food-grade solvents such as acetone, ethanol, and ethylacetate. [27, 28]

\section{CONCLUSION}

The present study identified twenty-five chemical compounds of acetone extract from the Helicteres hirsuta leaves. The studied extract was able to inhibit the growth of E. coli, P. aeruginosa, S. enteritidis, $S$. typhimurium, B. cereus, and $S$. aureus. Moreover, the extract also identified to have the antioxidant and cytotoxic activities in which Hepatoma (Hep-G2) cell line was killed with the $\mathrm{IC}_{50}$ of 381.8 ppm whereas this value was $1.223 \mathrm{mg} / \mathrm{mL}$ in DPPH inhibition. The results obtained in the study have shown the effective bioactivity of acetone extract from the $H$. hirsuta leaves and are the basis for its application in the prevention and treatment of diseases in the future.

\section{REFERENCES}

1. Cowie, I.D., New taxa and notes on'Helicteres' L.(Malvaceae: Helicteroideae) from the Northern Territory, Australia. Beagle: Records of the Museums and Art Galleries of the Northern Territory, The, 2011. 27: p. 27.

2. Mabberley, D.J., Mabberley's plant-book: a portable dictionary of plants, their classification and uses. 2008, Cambridge: Cambridge University Press.

3. Pham, H.H., An illustrated flora of Vietnam. Cây cỏ Việt Nam. Vol. 1. 1999: Youth Publication, Ho Chi Minh city.

4. Hoang, N.S., D.T. Bui, and T.N.T. Nguyen, A new species of Helicteres (Malvaceae) from southern Vietnam. Taiwania, 2020. 65(3): p. 321.

5. $\quad$ Nguyen, H.D.L., T.P., Chemical composition and toxicactive Hep-G2 Cells of Helicteres hirsuta L. Can Tho University Journal of Science, 2016. 47: p. 93-97.

6. Quang, D.N., et al., Cytotoxic constituents from Helicteres hirsuta collected in Vietnam. Natural product research, 2020. 34(4): p. 585-589.

7. Nguyen, T.T., et al., Triterpenoidal and Phenolic Compounds Isolated from the Aerial Parts of Helicteres hirsuta and their Cytotoxicity on Several Cancer Cell Lines. Natural Product Communications, 2019. 14(1): p. 1934578X1901400103. 
8. Dung, D.T.T., T.H. Trang, and D. Van Tan, Second metabolites and antioxidant, antimicrobial, anticancer activities of Helicteres hirsuta root extract. Academia Journal of Biology, 2018. 40(3).

9. Bobinaite, R., et al., Phytochemical composition, antioxidant and antimicrobial properties of raspberry fruit, pulp, and marc extracts. CyTA - Journal of Food, 2013. 11(4): p. 334-342.

10. Institute, C.a.L.S., Clinical and Laboratory Standards Institute, Methods for Antimicrobial Dilution and Disk Susceptibility of Infrequently Isolated or Fastidious Bacteria, Approved Guideline. 201 1: USA.

11. Thaipong, K., et al., Comparison of ABTS, DPPH, FRAP, and ORAC assays for estimating antioxidant activity from guava fruit extracts. Journal of food composition and analysis, 2006. 19(6-7): p. 669-675.

12. Hussain, R., A. Nouri, and R. Oliver, A new approach for measurement of cytotoxicity using colorimetric assay. Journal of immunological methods, 1993. 160(1): p. 89-96.

13. Rocha, O.P., et al., Chemical profile and biological potential of non-polar fractions from Centroceras clavulatum (C. Agardh) Montagne (Ceramiales, Rhodophyta). Molecules, 2011. 16(8): p. 7105-7114.

14. Hernández-Matamoros, A., et al., Determination of neophytadiene in the subcutaneous fat of Iberian pigs from different feeding systems. grasas y aceites, 2013. 64(2): p. 173-180.

15. Hidayati, L. and T.R. Nuringtyas, Secondary metabolite profiling of four host plants leaves of wild silk moth Attacus atlas L. Indonesian Journal of Biotechnology, 2016. 21(2): p. 117-124.

16. Cai, P., B.S. Kaphalia, and G.A. Ansari, Methyl palmitate: inhibitor of phagocytosis in primary rat Kupffer cells. Toxicology, 2005. 210(2-3): p. 197-204.

17. Fukunishi, H., et al., Role of a mutated residue at the entrance of the substrate access channel in cytochrome P450 engineered for vitamin D3 hydroxylation activity. Biochemistry, 2011. 50(39): p. 8302-8310.

18. Lee, Y.-C., et al., Role of perivascular adipose tissue-derived methyl palmitate in vascular tone regulation and pathogenesis of hypertension. Circulation, 2011. 124(10): p. 1160-1171.

19. Lee, Y.-C., et al., Methyl palmitate: a potent vasodilator released in the retina. Investigative ophthalmology \& visual science, 2010. 51(9): p. 4746-4753.

20. Crankshaw, D.J., J.M. Walsh, and J.J. Morrison, The effects of methyl palmitate, a putative regulator from perivascular fat, on the contractility of pregnant human myometrium. Life sciences, 2014. 116(1): p. 25-30.

21. Carta, G., et al., Palmitic acid: physiological role, metabolism and nutritional implications. Frontiers in physiology, 2017. 8: p. 902.

22. Islam, M.T., et al., Phytol: A review of biomedical activities. Food and chemical toxicology, 2018. 121: p. 82-94.

23. Wen, J., et al., Alpha- linolenic acid given as an anti-inflammatory agent in a mouse model of colonic inflammation. Food science \& nutrition, 2019. 7(12): p. 3873-3882.

24. Linton, R.E.A., S.L. Jerah, and I. Bin Ahmad, The effect of combination of octadecanoic acid, methyl ester and ribavirin against measles virus. Int J Sci Tech Res, 2013. 2(10): p. 181-184.

25. Tran, V.T.V., T.M.H., Study on antimicrobial and antioxidant activities of extract of Helicteres hirsute Lour, in The 7th National Conference on Ecology and Biologival Resources. 2017.

26. Hong, N., et al., Effect of extraction solvents and drying methods on the physicochemical and antioxidant properties of Helicteres hirsuta Lour. Leaves, 2015. 3: p. 285-301.

27. Chua, L.S., et al., Solvent fractionation and acetone precipitation for crude saponins from Eurycoma longifolia extract. Molecules, 2019. 24(7): p. 1416.

28. Adhikari, P., et al., Selection of solvent and extraction method for determination of antimicrobial potential of Taxus wallichiana Zucc. Research in Pharmacy, 2018. 8: p. 01-09. 


\section{THÀNH PHẦ HÓA HỌC VÀ HOẠT TÍNH KHÁNG KHUẨN, KHÁNG OXY HÓA, GÂY ĐỘC TẾ BÀO CỦ๋ DỊCH CHIẾT ACETONE TÙ' LÁ HELICTERES HIRSUTA LOUR.}

Tóm tắt: Trong nghiên cứu hiện tại, 25 hợp chất hóa học của chiết xuất aceton từ lá Helicteres hirsuta đã được phân tích lần đầu tiên bằng phương pháp $\mathrm{GC}-\mathrm{MS}$, trong đó các hợp chất neophytadiene, metyl este của acid palmitic, acid palmitic, phytol, acid linolenic và acid octadecanoic đã được xác định là các thành phần chính. Bằng phương pháp khuếch tán đĩa thạch, chiết xuất aceton từ lá Helicteres hirsuta có khả năng ức chế sự phát triển của 6 chủng vi khuẩn kiểm nghiệm, bao gồm Escherichia coli, Pseudomonas aeruginosa, Salmonella enteritidis, Salmonella typhimurium, Bacillus cereus và Staphylococcus aureus. Hơn nữa, các phương pháp DPPH và MTT đã được sử dụng để xác định các hoạt tính chống oxy hóa và gây độc tế bào của chiết xuất. Kết quả cho thấy chiết xuất có khả năng gây độc dòng tế bào ung thư gan (Hep-G2) với $\mathrm{IC}_{50}$ là $381,8 \mathrm{ppm}$ trong khi giá trị này là $1,223 \mathrm{mg} / \mathrm{mL}$ trong thử nghiệm ức chế $\mathrm{DPPH}$.

Từ khóa: Helicteres hirsuta; GC/MS; hoạt tính kháng khuẩn, kháng oxy hóa, gây độc tế bào; cao chiết acetone. 